\title{
Pediatric trauma due to motor vehicle accidents on high traffic roadway
}

\author{
Trauma pediátrico devido a acidente veicular em via de grande tráfego
}

\author{
Israel Figueiredo Junior ${ }^{1}$, Mauricio Vidal de Carvalho ${ }^{1}$, Glaucia Macedo de Lima $^{1}$
}

\begin{abstract}
Objective: To outline a profile of pediatric trauma victims and verify the likelihood of trauma in children on a high traffic roadway. Methods: A descriptive cohort study of the records of emergency medical service activations on the Rio-Niterói Bridge, a high traffic roadway in Rio de Janeiro, Brazil. Descriptive statistics were expressed as absolute and relative frequencies. The estimated risk of trauma in children aged $<12$ years was calculated by means of odds ratios, with a 95\% confidence interval. Results: Trauma accounted for 514 of 1,244 activations (41.31\%) of the Rio-Niterói Bridge emergency medical service between March 2002 and March 2003. Response to incidents involving children aged $<12$ years accounted for 52 of these $(4.18 \%)$. Half of victims were between the ages of 6 and 12 years $(n=26)$, and $55.76 \%$ were male $(n=29)$. Of the 52 victims, 37 $(71.15 \%)$ were involved in motor vehicle accidents (OR: $3.70 ; 95 \% \mathrm{Cl}$ : 1.94-7.13; $p<0.0001)$. Of these, 28 were vehicle-vehicle collisions (75.67\%). The most common sites of injury were the extremities $(n=12 ; 32.43 \%)$, face $(n=10 ; 27.02 \%)$, and head $(n=9 ; 24.32 \%)$. Pre-hospital procedures were performed on 23 of the 37 patients $(62.16 \%)$, and $44.23 \%(n=23 / 52)$ required hospital transportation. There were no deaths during the study period. Conclusions: In this study, children were at significantly higher odds of being treated for trauma while on a highway with heavy traffic flow. The most common sites of injury in this sample were the lower extremities and the head, face, and neck complex.
\end{abstract}

Keywords: Wounds and injuries; Emergency medical services; Accidents, traffic; Child

\section{RESUMO}

Objetivo: Caracterizar o perfil dos atendimentos pediátricos por trauma e verificar a chance de ocorrência de trauma em uma rodovia de alto fluxo de veículos. Métodos: Estudo de coorte descritivo dos dados armazenados nos boletins de atendimentos realizados por grupo de resgate pré-hospitalar da Ponte Rio-Niterói, uma via de grande tráfego, no Rio de Janeiro. Estatística descritiva foi aplicada utilizando-se a frequência simples e percentual, verificando-se o risco estimado de "trauma" em crianças $<12$ anos, por meio de odds ratio, com intervalo de confiança de 95\%. Resultados: Em 1.244 atendimentos, entre março de 2002 e março de 2003, trauma representou $41,31 \%$ $(\mathrm{n}=514), 76 \%$ do sexo masculino dos casos. 0 atendimento a crianças de até 12 anos correspondeu a 4,18\% ( $n=52)$ e metade das vítimas tinha entre 6 e 12 anos $(n=26)$, sendo $29(55,76 \%)$ do sexo masculino. Entre as 52 vítimas, $71,15 \%(n=37)$ estavam envolvidas em acidente de trânsito (OR: 3,70; IC95\%: 1,94-7,13; $p<0,0001$ ), sendo $28(75,67 \%)$ colisões. Os locais mais frequentes de lesões foram extremidades $(n=12 ; 32,43 \%)$, face ( $n=10 ; 27,02 \%)$ e cabeça $(\mathrm{n}=9 ; 24,32 \%)$. Os procedimentos pré-hospitalares foram realizados em 23 dos 37 pacientes $(62,16 \%)$ e $44,23 \%(n=23 / 52)$ necessitaram de remoção hospitalar. Não houve óbito pediátrico durante o período analisado. Conclusões: Neste estudo as crianças apresentaram maior probabilidade de serem tratadas para traumatismo nessa rodovia de intenso fluxo de veículos. Os locais mais frequentes de lesões foram membros inferiores e o complexo cabeça, face e pescoço.

Descritores: Ferimentos e lesões; Serviços médicos de emergência; Acidentes de trânsito; Criança

\section{INTRODUCTION}

Pediatric trauma is a growing public health concern ${ }^{(1)}$. Trauma care in children is a specialized endeavor, and has several distinguishing features.

Recent literature stresses the paucity of guidelines directed at the pediatric trauma population, as well as the need for studies of quality indicators in pediatric trauma care ${ }^{(2)}$. In an attempt to revert this scenario, some authors suggested the development of a basic curriculum for education of professionals who manage pediatric trauma ${ }^{(3)}$. Motor vehicle accidents occurring

\footnotetext{
Study carried out at Universidade Federal Fluminense - UFF, Niterói (RJ), Brazil.

1 Univeridade Federal Fluminense - UFF, Niterói (RJ), Brazil.

Corresponding author: Israel Figueiredo Junior - Avenida Marquês do Paraná, 303 - Centro - Zip Code: 24030-210 - Niterói (RJ), Brasil - Phone.: (21) 2629-9028 - E-mail: ifigueiredo@id.uff.br

Received on: Aug 7, 2011 - Accepted on: Feb 7, 2012

Conflict of interest: None
} 
on high traffic flow roadways are challenging events, and their management requires specific training.

In a six-year study of causes of death in children aged 0 to 17 years, Fraga et al. concluded that the predominant mechanisms of injury are secondary to road traffic accidents, followed by asphyxia and penetrating trauma; furthermore, they found that $40.9 \%$ of trauma deaths in this population occurred at the scene of the accident ${ }^{(4)}$. A study of children admitted to Intensive Care Units (ICU) found that traffic accident injuries were most prevalent, along with trauma due to falls and burns ${ }^{(5)}$.

Traffic is clearly an unsafe setting for children, which can lead to death, or permanent and irreversible injury, with a heavy cost to society ${ }^{(6)}$.

\section{OBJECTIVE}

The objective of this study was to outline a profile of pre-hospital care of pediatric trauma victims in this setting, with an emphasis on the injuries occurring in this population and to verify the likelihood of trauma in children on a high traffic roadway.

\section{METHODS}

This study consisted of a cross-section review of electronic records of pre-hospital emergency medical responses to incidents on the Rio-Niterói Bridge involving at least one child aged 0 to 12 years and occurring between March 2002 and March 2003.

Cases were stratified by patient age (less than or up to 12 years), and, in each group, by whether or not traumatic injury occurred while traversing the bridge.

Data of interest were entered into a record specifically designed for the purposes of this study, containing fields for the month in which the event took place, patient age and sex, disposition after pre-hospital care, type of accident, type of traumatic injury, need for and type of pre-hospital intervention, and mortality.

Injuries were classified by region (face, head and neck, chest, abdomen, spine, upper extremities, and lower extremities).

Throughout the study period, the pre-hospital care teams serving the roadway of interest consisted of a physician, an emergency medical technician, and an experienced emergency vehicle operator, all of whom received continuous, specialized, in-house training. Only Advanced Life Support (ALS) units are used by this service, in order to enable provision of immediate care in any medical emergency occurring along the $13-\mathrm{km}$ span of the bridge.
The Rio-Niterói Bridge is part of the road BR-101, one of the main interstate highways of Brazil, and is privately operated under a concession awarded to a publicly traded company. The bridge carries a heavy flow of traffic. Law enforcement is provided by the Federal Highway Police, which also operates a command center that records all incidents.

The study project was approved by the Universidade Federal Fluminense (UFF) Research Ethics Committee. There were no relevant conflicts of interest.

Descriptive statistics were expressed as absolute and relative frequency, calculating the estimated risk of trauma for each population as an outcome variable, using the odds ratio (OR) and a 95\% confidence interval $(95 \% \mathrm{CI})$. The StatCalc module of the Epi-Info software package was used for analysis.

\section{RESULTS}

Trauma accounted for 514 of 1,244 pre-hospital responses $(41.31 \%)$ in our sample. Of these calls, 52 (4.18\%) were related to children aged $<12$ years; calls involving children occurred most often in December. Victims were male in 29 cases $(55.76 \%)$; half of all calls $(n=26)$ involved children between 6 and 12 years of age. Of the 52 pediatric victims seen, $37(71.15 \%)$ were involved in motor vehicle accidents (OR: 3.70; 95\% CI: 1.94-7.13; $\mathrm{p}<0.0001)$. Vehicle-vehicle collisions accounted for 28 of these accidents (75.67\%), 23 of which (62.16\%) occurred on the Niterói-bound side of the bridge. Children were unrestrained backseat passengers in 23 of the 37 accidents $(62.16 \%)$. The most common sites of injury were $\operatorname{limbs}(\mathrm{n}=12 ; 32.43 \%)$, face $(\mathrm{n}=10 ; 27.02 \%)$, and head $(\mathrm{n}=9 ; 24.32 \%)$. Pre-hospital care procedures were performed on 23 of the 37 patients $(62.16 \%)$. The main procedures performed were immobilization on a long spine board $(\mathrm{n}=15 ; 40.54 \%)$ and with cervical collar $(\mathrm{n}=14 ; 37.83 \%)$. Of the 52 children treated, 23 $(44.23 \%)$ required hospital transport. There were no pediatric deaths during the study period.

\section{DISCUSSION}

Trauma figures have haunted the world in recent times. It is estimated that approximately 1.5 million Americans suffer a traumatic brain injury every year, $80 \%$ of them considered mild ${ }^{(7)}$. Although no deaths occurred in the cohort discussed herein, all children in the study sample sustained - at the very least - mild traumatic brain injury, which may lead to a wide range of outcomes, from spontaneous resolution to poorly measurable functional deficits (the latter particularly in children). 
Fortunately, in our sample, few newborns and infants were involved in accidents; most victims were in the 6 to 12-year range. Children in this age group are naturally at an increased risk of vehicular trauma, since they are often taken on car trips by their parents or relatives (which would also explain the preponderance of accidents in December). The seasonal fluctuation in accident rates found in this study has another obvious explanation: school holidays, which alone would justify our findings, according to Duma ${ }^{(8)}$, who found that road trauma was most common in the summer. Furthermore, in the summer, trips to the Lake Region in the state of Rio de Janeiro are frequent, which would explain more Niterói-bound traffic. This should serve as a warning to authorities, prompting them to improve enforcement of legislation concerning the use of seat belts and backseat restraints.

The near-30\% rate of clinical emergency-related responses was also surprising, as we only expected to find records of trauma calls on the bridge. Lower limb injuries were the most common lesions in trauma patients. This is consistent with the findings of prior studies ${ }^{(9,10)}$. Some analyses showed that victims sustaining severe abdominal, chest, and lower extremity injuries are less likely to survive during hospitalization ${ }^{(11)}$. A recent study demonstrated the usefulness of ultrasound in ruling out hidden or hairline fractures of immature bones in pediatric patients ${ }^{(12)}$. Our findings are consistent with those described by Huang ${ }^{(13)}$, who found that injuries of the face, head, and neck were most prevalent, surpassed only by extremity injuries. Interestingly, the distribution of injuries reported in our sample was similar to that found after a bomb attack ${ }^{(14)}$. Countless reports and studies focused on head injury ${ }^{(7,15-17)}$, facial injury (including possible dental involvement) ${ }^{(18-20)}$, and eyes $^{(21)}$, jaw ${ }^{(22)}$, and other regions. Although there is no standard approach for ruling out cervical spine injury in young children ${ }^{(23)}$, this procedure is mandatory, particularly due to lack of patient cooperation, difficulty communicating, and the possibility of severe injury requiring intubation and sedation ${ }^{(23-25)}$. It should be stressed that, when the scene is unsafe or the patient is clinically unstable, rapid extrication is indicated regardless of age, with comprehensive immobilization waived in favor of quick removal from the scene. Our data show that emergency medical responders serving the Rio-Niterói Bridge are well-trained in immobilizing the cervical spine when subluxation is a possibility.

Regarding pre-hospital traumatic cardiopulmonary arrest, which did not occur in the study sample, responders should bear in mind that adult protocols are to be followed in young victims with signs of puberty (axillary hair in males, breast development in females)(26). In this context, current clinical criteria for termination of resuscitation efforts in the field include absent pulse, unorganized electrocardiogram, fixed pupils (all at the accident scene) and cardiopulmonary resuscitation for more than 15 minutes $^{(27)}$. The importance of this guideline dates back to 1994, considering that accidents remain a major cause of ICU admission and death in children $^{(28,29)}$.

One of the key contributions of the present study was the finding that the odds and relative risk of a child under 12 years being treated for trauma sustained while traversing the Rio-Niterói Bridge were over 3.5 times as compared to clinical cases. This finding is relevant enough to recommend that pre-hospital care teams be prepared cognitively, physically, and in terms of equipment to treat children between the neonatal period and adolescence.

Finally, a multifactorial approach including a combination of professional and family training ${ }^{(30)}$, use of appropriate tools for treatment and prognosis ${ }^{(31,32)}$, and implementation of new technologies for the prevention and initial assessment of adult and pediatric trauma patients ${ }^{(33)}$ should be pursued in an attempt to reverse these trauma-related indicators.

\section{CONCLUSIONS}

In this study, children were at significantly higher odds of being treated for trauma, sustained while traversing a high traffic bridge. The most common sites of injury in this sample were the lower extremities and head, face, and neck complex. Continuous assessment of pediatric trauma indicators must take place if effective policies for prevention and management of this phenomenon are to be persistently implemented.

\section{REFERENCES}

1. Sengoelge $M$, Hasselberg $M$, Laflamme L. Child home injury mortality in Europe: a 16-country analysis. Eur J Public Health. 2011;21(2):166-70.

2. Stelfox HT, Bobranska-Artiuch B, Nathens A, Straus SE. A systematic review of quality indicators for evaluating pediatric trauma care. Crit Care Med. 2010;38(4):1187-96.

3. Valani RA, Yanchar N, Grant V, Hancock BJ. The development of a nationa pediatric trauma curriculum. Med Teach. 2010;32(3):e115-9.

4. Fraga AM, Fraga GP, Stanley C, Costantini TW, Coimbra R. Children at danger: injury fatalities among children in San DiegoCounty. Eur J Epidemiol. 2010;25(3):211-7.

5. Hon KL, Leung TF, Cheung KL, Nip SY, Ng J, Fok TF, et al. Severe childhood injuries and poisoning in a densely populated city: where do they occur and what type? J Crit Care. 2010;25(1):175. e7-12.

6. Winthrop AL. Health-related quality of life after pediatric trauma. Curr Opin Pediatr. 2010;22(3):346-51.

7. Yu Z, Morrison B, 3rd. Experimental mild traumatic brain injury induces functional alteration of the developing hippocampus. J Neurophysiol. 2010; 103(1):499-510. 
8. Duma 0, Rosu TS. [Soliciting a model of a child emergency care unit in road accidents in the year 2005]. Rev Med Chir Soc Med Nat lasi. 2006;110(4): 999-1003. Romanian.

9. Laine JC, Kaiser SP, Diab M. High-risk pediatric orthopedic pitfalls. Emerg Med Clin North Am. 2010;28(1):85-102, viii.

10. Enweluzo GO, Giwa SO, ObalumDC. Pattern of extremity injuries in polytrauma in Lagos, Nigeria. Niger Postgrad Med J. 2008;15(1):6-9.

11. Malvestio MA, Sousa RM. Sobrevivência após acidentes de trânsito: impacto das variáveis clínicas e pré-hospitalares. Rev Saude Publica. 2008;42(4): 639-47.

12. Cho KH, Lee SM, Lee YH, Suh KJ. Ultrasound diagnosis of either an occult or missed fracture of an extremity in pediatric-aged children. Korean J Radiol. 2010;11(1):84-94.

13. Huang SX, Li SY, Zhang XG, Kong B, Zhu YL, Liu KL. [Epidemiological research and analysis on the impaired person in road traffic accident in Chengdu area]. Fa Yi Xue Za Zhi. 2007;23(4):269-73. Chinese.

14. Kim D, Mosher B, Morrison CA, Parker-Lee C, Opreanu RC, Stevens P, et al. A modern analysis of a historical pediatric disaster: the 1927 Bathschool bombing. J Surg Res. 2010;163(2):309-16.

15. Sandler SJ, Figaji AA, Adelson PD. Clinical applications of biomarkers in pediatric traumatic brain injury. Childs Nerv Syst. 2010;26(2):205-13.

16. Walker PA, Jimenez F, Cox CS Jr. Progenitor cell therapy for traumatic brain injury: effect of serum osmolarity on cell viability and cytokine production. Regen Med. 2010;5(1):65-71.

17. Scaife ER, Statler KD. Traumatic brain injury: preferred methods and targets for resuscitation. Curr Opin Pediatr. 2010;22(3):339-45.

18. Wendt FP, Torriani DD, Assunção MC, Romano AR, Bonow ML, da Costa CT, et al. Traumatic dental injuries in primary dentition: epidemiological study among preschool children in South Brazil. Dent Traumatol. 2010;26(2):168-73.

19. Khan NA, Oazi HS, Maxood A, Khan AM, Abbas I. Traumatic injuries of the permanent maxillory incisors at Dental Department, Pakistan Institute of Medical Sciences Islamabad: a retrospective study. J Ayub Med Coll Abbottabad. 2008;20(3):84-7.

20. Jesus MA, Antunes LA, Risso P de A, Freire MV, Maia LC. Epidemiologic survey of traumatic dental injuries in children seen at the Federal University of Rio de Janeiro, Brazil. Braz Oral Res. 2010;24(1):89-94.

21. Liu ML, Chang YS, Tseng SH, Cheng HC, Huang FC, Shih MH, et al. Major pediatric ocular trauma in Taiwan. J Pediatr Ophthalmol Strabismus. 2010; 47(2):88-95.

22. Okoje VN, Alonge TO, Oluteye OA, Denloye 00. Changing pattern of pediatric maxillofacial injuries at the Accident and Emergency Department of the University Teaching Hospital, Ibadan-a four-year experience. Prehosp Disaster Med. 2010;25(1):68-71.

23. Anderson RC, Kan P, Vanaman M, Rubsam J, Hansen KW, Scaife ER, et al. Utility of a cervical spine clearance protocol after trauma in children between 0 and 3 years of age. J Neurosurg Pediatr. 2010;5(3):292-6.

24. Easter JS, Barkin R, Rosen CL, Ban K. Cervical spine injuries in children, part II: Management and special considerations. J Emerg Med. 2011;41(3):252-6.

25. Easter JS, Barkin R, Rosen CL, Ban K. Cervical spine injuries in children, part l: mechanism of injury, clinical presentation, and imaging. J Emerg Med. 2011; 41(2):142-50.

26. Berg MD, Schexnayder SM, Chameides L, Terry M, Donoghue A, Hickey RW, et al. Part 13: pediatric basic life support: 2010 American Heart Association Guidelines for Cardiopulmonary Resuscitation and Emergency Cardiovascular Care. Circulation. 2010;122(18 Suppl 3):S862-75.

27. Capizzani AR, Drongowski R, Ehrlich PF. Assessment of termination of trauma resuscitation guidelines: are children small adults? J Pediatr Surg. 2010;45(5):903-7.

28. Freitas SL, Gandara CA, Flores I, Pires F. Trauma pediátrico: avaliação de 2 anos em UTI pediátrica Rev Cient AMECS. 1994;3(2):131-4.

29. Martins CB, Andrade SM. Causas externas entre menores de 15 anos em cidade do Sul do Brasil: atendimentos em pronto-socorro, internações e óbitos. Rev Bras Epidemiol. 2005;8(2):194-204.

30. Kingsnorth J, O'Connell K, Guzzetta CE, Edens JC, Atabaki S, Mecherikunnel $A$, et al. Family presence during trauma activations and medical resuscitations in a pediatric emergency department: an evidence-based practice project. J Emerg Nurs. 2010;36(2):115-21.

31. Schluter PJ, Nathens A, Neal ML, Goble S, Cameron CM, Davey TM, et al. Trauma and Injury Severity Score (TRISS) coefficients 2009 revision. J Trauma. 2010;68(4):761-70.

32. Taori RN, Lahiri KR, Tullu MS. Performance of PRISM (Pediatric Risk of Mortality) score and PIM (Pediatric Index of Mortality) score in a tertiary care pediatric ICU. Indian J Pediatr. 2010;77(3):267-71.

33. Moulton SL, Haley-Andrews S, Mulligan J. Emerging technologies for pediatric and adult trauma care. Curr Opin Pediatr. 2010;22(3):332-8. 